\title{
Business angels jako alternatywne źródto finansowania start-upów
}

\author{
Gabriela Golawska-Witkowska*, Ewa Mazurek-Krasodomska**, Anna Rzeczycka***
}

\section{Wprowadzenie}

Podmioty gospodarcze, będąc elementem każdego modelu gospodarki, są istotne z punktu widzenia funkcjonowania każdego systemu ekonomicznego na świecie. Stan gospodarki jest bowiem silnie zależny od dynamicznego rozwoju sektora przedsiębiorczości. Relacja ta zachodzi na wszystkich etapach postępu gospodarczego, może jednak przybierać różne nasilenie i charakter.

W Polsce, podobnie jak na całym świecie, powstaje wiele nowych przedsiębiorstw. Główną barierą ich rozwoju w początkowej fazie jest niewątpliwie brak kapitału. Wdrożenie i realizacja obiecujących pomysłów są bardzo często niemożliwe z powodu braku funduszy.

Celem niniejszego artykułu jest ocena roli aniołów biznesu w finansowaniu przedsiębiorstw w zalążkowej lub początkowej fazie rozwoju.

* Gabriela Golawska-Witkowska, Politechnika Gdańska, Wydział Zarządzania i Ekonomii, Katedra Analizy Ekonomicznej i Finansów, g.golawska@gmail.com

** Ewa Mazurek-Krasodomska, Politechnika Gdańska, Wydział Zarządzania i Ekonomii, Katedra Analizy Ekonomicznej i Finansów, emazurek@zie.pg.gda.pl

${ }^{\star \star \star}$ Anna Rzeczycka, Politechnika Gdańska, Wydział Zarządzania i Ekonomii, Katedra Analizy Ekonomicznej i Finansów, rzeczycka@interia.pl 


\section{Działalność gospodarcza w Polsce}

Małe i średnie przedsiębiorstwa są motorem rozwoju gospodarczego współczesnych krajów. To jeden z wiodących elementów gospodarki, który w znacznym stopniu wpływa na wzrost gospodarczy oraz poziom zatrudnienia. Uwzględniając skomplikowaną sieć powiązań i zależności między uwarunkowaniami przedsiębiorczości, cechami indywidualnych przedsiębiorców, rodzajem powstających przedsięwzięć i efektami ich funkcjonowania, oddziałującymi zarówno na życie społeczne, jak i gospodarcze, dokonano podziału krajów według fazy rozwoju gospodarczego na trzy grupy (tab. 1) (Porter, Sachs, Mc Arthur 2002):

- zorientowane na czynniki produkcji,

- zorientowane na efektywność,

- zorientowane na innowacje.

Tabela 1. Trzy fazy rozwoju gospodarczego i ich charakterystyka

\begin{tabular}{|c|c|c|}
\hline $\begin{array}{l}\text { Kraje zorientowane } \\
\text { na czynniki produkcji }\end{array}$ & $\begin{array}{c}\text { Kraje zorientowane } \\
\text { na efektywność }\end{array}$ & $\begin{array}{l}\text { Kraje zorientowane } \\
\text { na innowacje }\end{array}$ \\
\hline $\begin{array}{l}\text { - konkurencja odbywa się } \\
\text { na poziomie czynników } \\
\text { produkcji, takich jak praca } \\
\text { czy zasoby naturalne, } \\
\text { - cena jest głównym czynni- } \\
\text { kiem konkurowania przed- } \\
\text { siębiorstw na rynku, } \\
\text { - produktywność jest niska, } \\
\text { - niskie są również koszty } \\
\text { pracy, } \\
\text { - państwo powinno wspierać } \\
\text { rozwój instytucji, infra- } \\
\text { struktury, stabilność } \\
\text { makroekonomiczną oraz } \\
\text { zapewnić efektywny } \\
\text { system opieki zdrowotnej } \\
\text { i podstawowej edukacji. }\end{array}$ & $\begin{array}{l}\text { - wraz z rosnącymi koszta- } \\
\text { mi pracy muszą tworzyć } \\
\text { bardziej efektywne metody } \\
\text { produkcji, } \\
\text { - jakość produktów i usług } \\
\text { jest głównym czynnikiem } \\
\text { konkurencji na rynku, } \\
\text { - zadaniem państwa jest } \\
\text { poprawa funkcjonowania } \\
\text { rynków kapitałowych } \\
\text { oraz pracy, przyciąganie } \\
\text { inwestycji zagranicznych } \\
\text { i tworzenie systemów } \\
\text { edukacyjnych umożliwiają- } \\
\text { cych kształcenie w zakresie } \\
\text { adaptowania technologii. }\end{array}$ & $\begin{array}{l}\text { - mogą utrzymać wysokie } \\
\text { wynagrodzenia i odpo- } \\
\text { wiedni standard życia tylko } \\
\text { wtedy, kiedy przedsiębior- } \\
\text { stwa są w stanie konkuro- } \\
\text { wać, opierając się na no- } \\
\text { wych i wyspecjalizowanych } \\
\text { produktach i innych inno- } \\
\text { wacyjnych rozwiązaniach, } \\
\text { - kluczowa rola państwa } \\
\text { tkwi w tworzeniu i komer- } \\
\text { cjalizacji wiedzy. }\end{array}$ \\
\hline
\end{tabular}

Źródto: opracowanie własne na podstawie Bosma, Wennekers, Amoros 2012, s. 13.

Polska w 2014 roku, podobnie jak w poprzednich latach, została zaliczona do gospodarek zorientowanych na efektywność․ Jednak, patrząc na odsetek firm znajdujących się w różnych fazach rozwoju, jest ona bliższa grupie krajów innowacyjnych niż tych zorientowanych na efektywność (wykres 1 i 2).

1 Kraje przypisywane są do danej grupy zgodnie z podziałem przyjętym w Global Competitiveness Report wydawanym przez Światowe Forum Gospodarcze. 


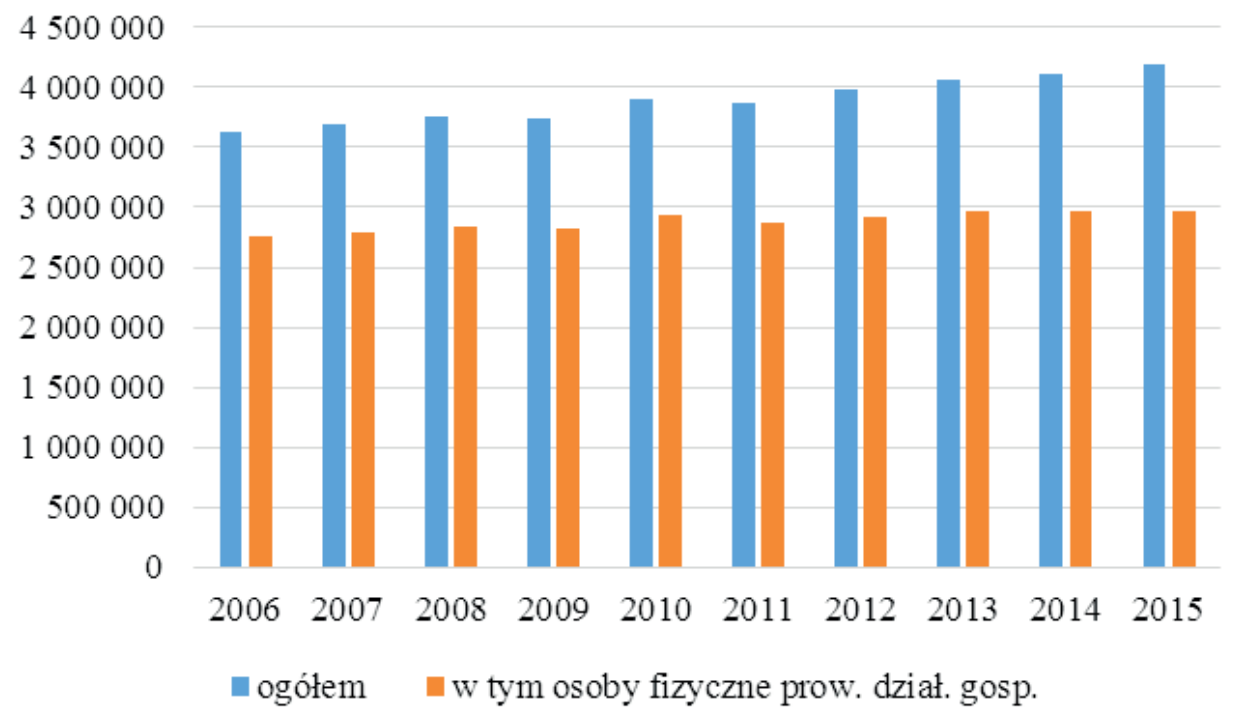

Wykres 1. Podmioty gospodarcze w Polsce w latach 2006-2015 Źródto: opracowanie własne na podstawie www.stat.gov.pl.

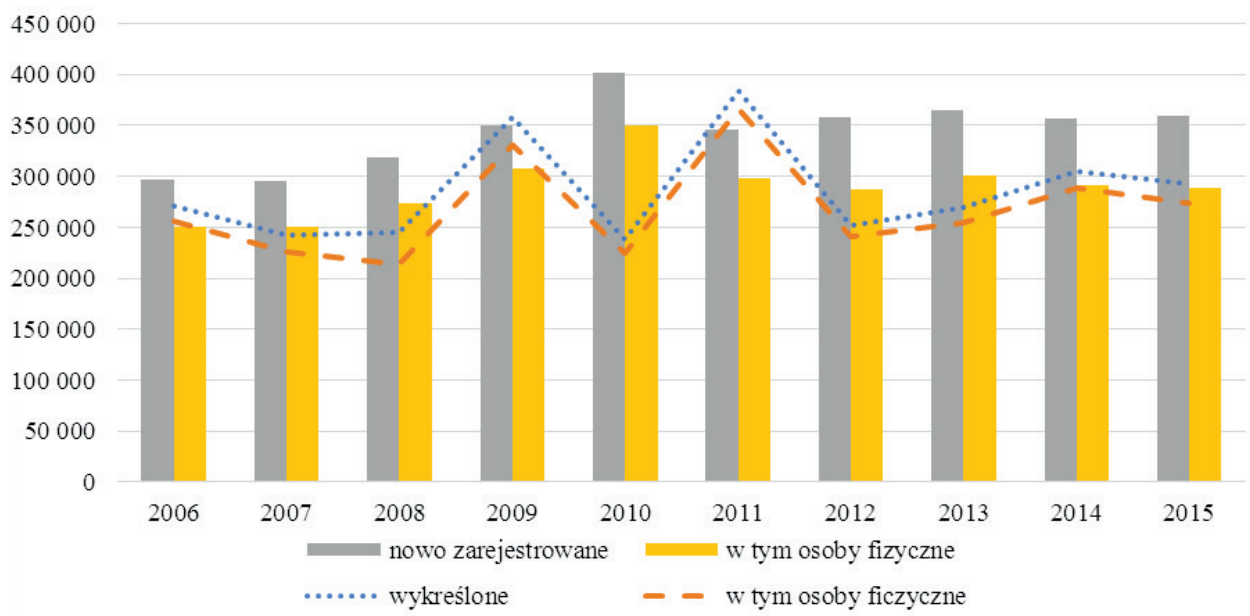

Wykres 2. Podmioty gospodarcze nowo zarejestrowane i wykreślone w latach 2006-2015 Źródło: opracowanie własne na podstawie www.stat.gov.pl.

Różne są motywy podjęcia decyzji o rozpoczęciu działalności gospodarczej. Generalnie uwzględnia się:

- wykorzystanie szansy, która prowadzi do uzyskania niezależności i wzrostu dochodów osobistych, a tym samym prowadzi do poprawy standardu życia,

- konieczność założenia własnej firmy jako alternatywy w postaci znalezienia zatrudnienia na rynku pracy. 
Tabela 2. Motywy rozpoczęcia działalności gospodarczej w Polsce na tle innych gospodarek (\% przedsiębiorstw we wczesnym stadium rozwoju)

\begin{tabular}{|l|c|c|}
\hline \multicolumn{1}{|c|}{ Gospodarka } & $\begin{array}{c}\text { Szansa poprawy } \\
\text { standardu życia }\end{array}$ & $\begin{array}{c}\text { Konieczność } \\
\text { zatożenia firmy }\end{array}$ \\
\hline Zorientowana na czynniki produkcji & 47,03 & 28,16 \\
\hline Zorientowana na efektywność & 45,08 & 27,25 \\
\hline Zorientowana na innowacje & 54,91 & 17,96 \\
\hline Średnia dla UE & 47,9 & 22,8 \\
\hline Polska & 47,11 & 36,75 \\
\hline
\end{tabular}

Źródło: opracowanie własne na podstawie Raportu z badania Global Entrepreneurship Monitor - Polska 2014.

W 2014 roku po raz pierwszy w Polsce motyw w postaci szansy na poprawę standardu życia wyprzedził przymus założenia nowego przedsiębiorstwa, wynikający z ograniczonych możliwości zatrudnienia (wykres 3).

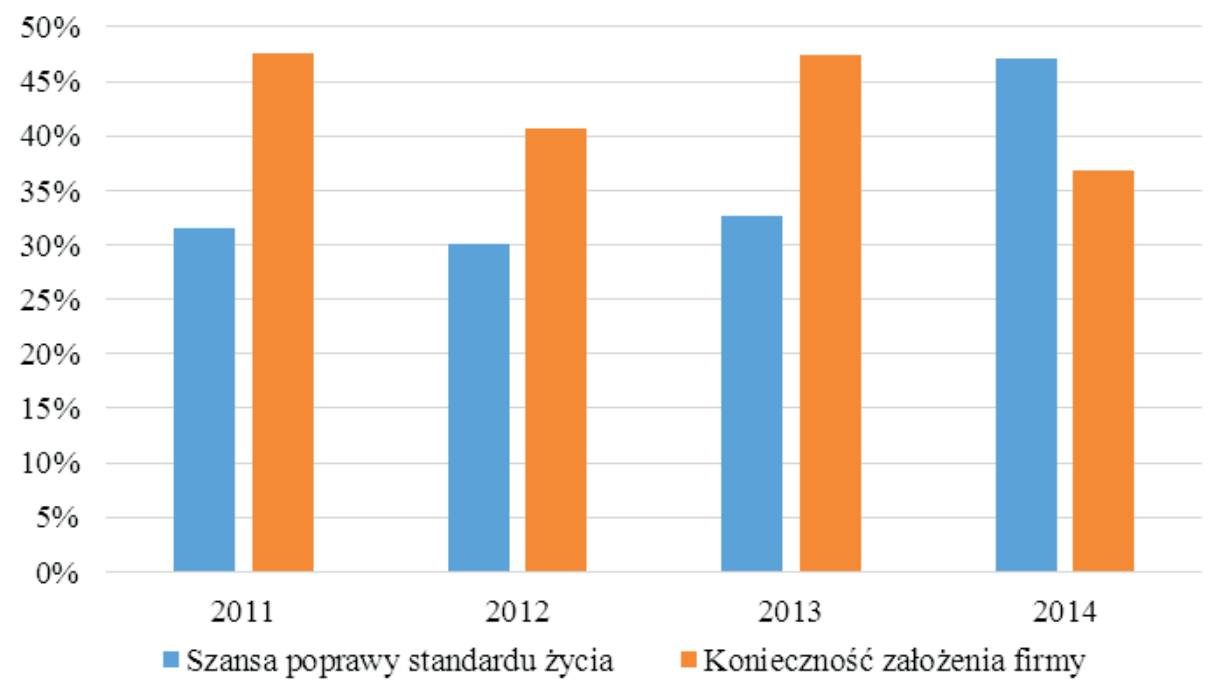

Wykres 3. Motywy rozpoczęcia działalności gospodarczej w Polsce w latach 2011-2014 (\% przedsiębiorstw we wczesnym stadium rozwoju)

Źródło: opracowanie własne na podstawie danych Global Entrepreneurship Monitor 2011-2014.

Coraz więcej młodych osób rozpoczyna działalność gospodarczą (wykres 4). W ostatnim czasie nawet w środowisku studenckim popularne stało się zakładanie własnych firm. Z reguły nie są to duże przedsiębiorstwa, lecz niewielkich rozmiarów start-upy. Badania przeprowadzone przez autorki wśród studentów Politechniki Gdańskiej potwierdzają tę tendencję. $46 \%$ ankietowanych studentów planuje po ukończeniu studiów rozpoczęcie własnej działalności gospodarczej. 6,8\% studentów studiów niestacjonarnych oraz 2,3\% studentów stacjonarnych już prowadzi własną firmę i deklaruje dalszą chęć utrzymywania się z tego źródła. 


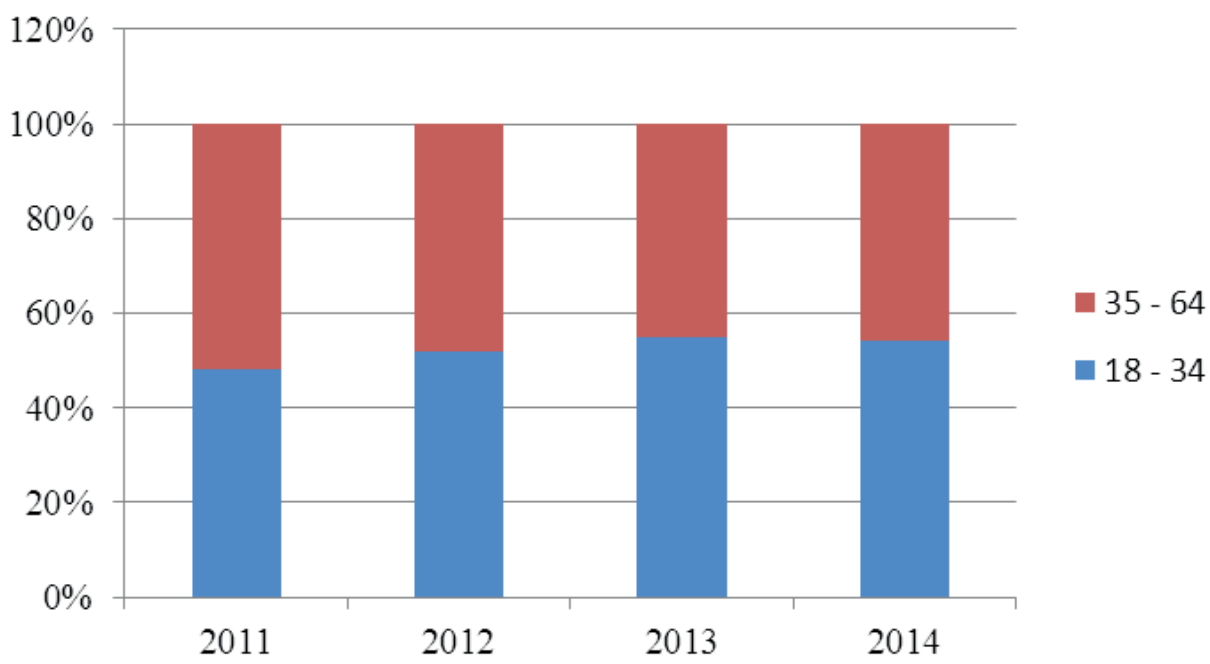

Wykres 4. Struktura wiekowa nowych przedsiębiorców w Polsce w latach 2011-2014 Źródło: opracowanie własne na podstawie danych Global Entrepreneurship Monitor 2011-2014.

Ważnym czynnikiem wpływającym na konkurencyjność kraju są firmy o wysokim potencjale wzrostu, innowacyjne i podejmujące działalność poza granicami kraju.

\section{Start-up - pomyst na własną firmę}

We współczesnym świecie coraz większą rolę odgrywają innowacje i nowe technologie, które pozwalają w dynamiczny sposób rozwijać różne dziedziny gospodarki. Ludzie mający bujną wyobraźnię, chcąc realizować swoje pasje, próbują swoje pomysły wcielić w życie. Idealnym rozwiązaniem dla takiej jednostki jest stworzenie swojego własnego małego biznesu, jakim jest start-up.

Start-up to nowa, mała firma, która dopiero zaczyna się rozwijać. W zasadzie wszystkie nowo powstające przedsiębiorstwa $\mathrm{w}$ różnych sektorach gospodarki można byłoby nazwać start-upami, jednak miano to zarezerwowano dla firm branży nowych technologii, zajmujących się handlem elektronicznym, biotechnologią, nanotechnologią czy też inżynierią kosmiczną. Start-up to firma z pomysłem na przedsięwzięcie, która poszukuje szybkiego wzrostu, a także modelu biznesowego, który przyniesie bardzo wysokie zyski. Charakteryzuje ją niski koszt początkowy, wyższe niż w standardowych firmach ryzyko biznesowe, a także potencjalny wyższy zwrot $\mathrm{z}$ inwestycji, kiedy przedsiębiorstwo zdobędzie stabilizację rynkową. Start-upy powinny więc znaleźć niszę, dzięki której zdobędą przewagę nad konkurencją. 
Nowi przedsiębiorcy w Polsce są innowacyjni, wykorzystują nowe technologie i mają ambicje do szybkiego wzrostu firmy (wykres 5).

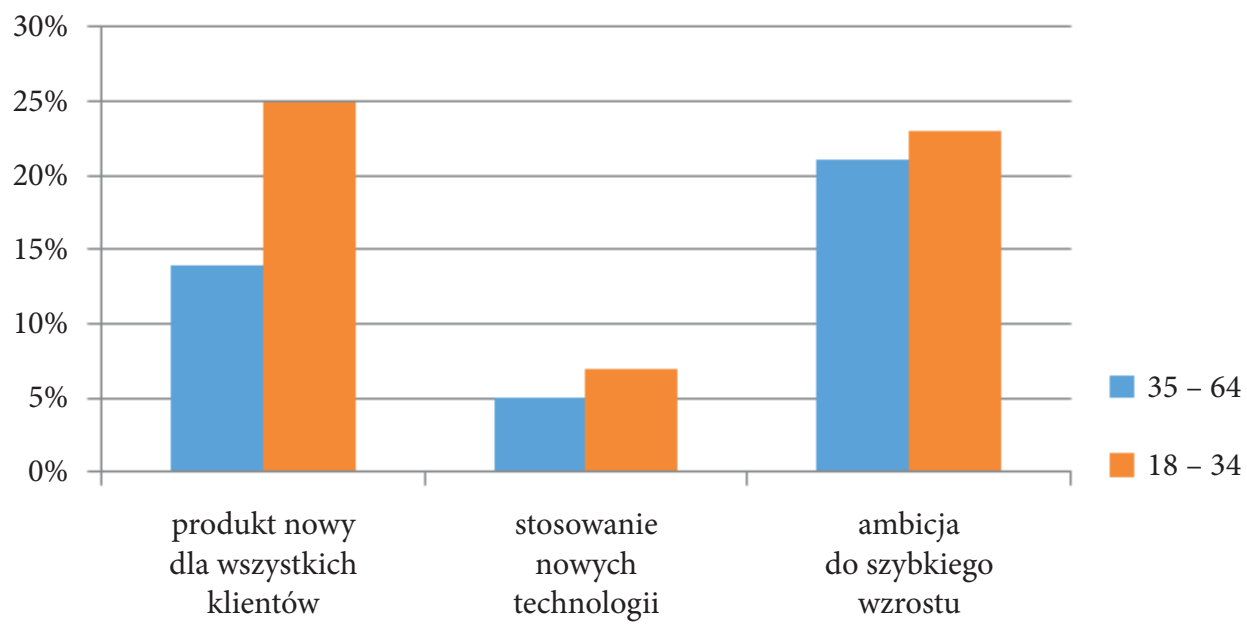

Wykres 5. Nowi przedsiębiorcy w Polsce i ich charakterystyka w grupach wiekowych

Źródło: opracowanie własne na podstawie Global Entrepreneurship Monitor - Polska 2014.

Jak widać, to właśnie młodzi przedsiębiorcy są bardziej innowacyjni (25\% z nich oferuje produkt, który jest nowy dla wszystkich klientów), w większym stopniu stosują nowe technologie i mają większe ambicje do realizacji szybkiego wzrostu firmy w porównaniu z pozostałymi przedsiębiorcami. Nowo zakładane i innowacyjne przedsiębiorstwa obciążone są wysokim ryzykiem i tradycyjne źródła finansowania są dla nich trudno dostępne.

\section{Business angels w finansowaniu start-upów}

Brak lub też bardzo ograniczony dostęp do źródeł finansowania jest barierą hamującą proces powstawania nowych firm i ich rozwoju. Problem ten dotyka w szczególności podmiotów gospodarczych w początkowej fazie cyklu życia firmy, a więc również start-upów. Nowi przedsiębiorcy, którzy z ogromnym trudem próbują wejść z pomysłem na nasycony rynek, rzadko mają możliwość realizacji innowacyjnego projektu, opierając się wyłącznie na własnych środkach finansowych, i szukają zewnętrznych źródeł wsparcia finansowego, które pozwoli im spełnić swoje marzenia i rozpocząć przygodę ze światem biznesu (rysunek 1). 


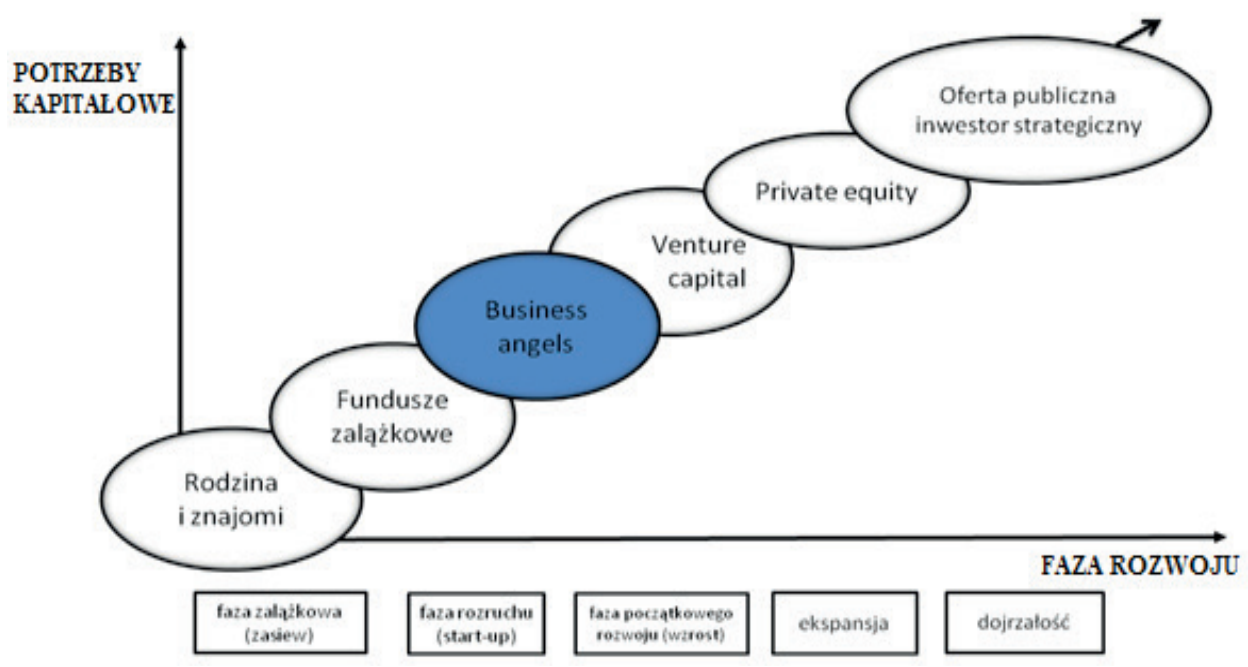

Rysunek 1. Źródła finansowania a etap rozwoju przedsiębiorstwa

Źródto: opracowanie własne.

Dla instytucji finansowych pomysły innowacyjne są na tyle ryzykowne, że nie decydują się na ich sponsorowanie. Dlatego też firmom nowym, których przyszła pozycja na rynku jest niewiadomą, z pomocą przychodzą aniołowie biznesu.

Business angels są zainteresowane finansowaniem małych i średnich przedsiębiorstw, które $\mathrm{z}$ reguły są we wczesnym stadium rozwoju i wykazują się dużym potencjałem wzrostu swojej wartości. Tworzone są przez prywatnych inwestorów, a więc osoby fizyczne bądź grupy osób prowadzące regularną działalność inwestycyjną podwyższonego ryzyka, które inwestują kapitał własny w obiecujące nowe przedsięwzięcia (Tamowicz 2007, s. 8). Są to przedsiębiorcy z dużym doświadczeniem zawodowym, posiadający samodzielnie wypracowany znaczny majątek, którzy angażują nie tylko zgromadzone oszczędności, ale także swoje doświadczenie biznesowe, wiedzę i kontakty handlowe.

Aniołowie są nie tylko pierwszymi kapitałodawcami firmy, ale również ich mentorami, tak więc motywy ich działania mają zarówno wymiar finansowy, jak i osobisty, ambicjonalny (Michalski, Piocha 2008, s. 403). Aktywność aniołów biznesu ma charakter głównie lokalny, co oznacza, że przedmiotem ich inwestycji są firmy niedaleko oddalone od miejsca zamieszkania inwestora, by możliwe było utrzymywanie częstych kontaktów osobistych z przedsiębiorcą w celach doradczych (wykres 6). Aniołowie biznesu często bowiem aktywnie uczestniczą w życiu wspieranej firmy.

W literaturze przedmiotu można znaleźć kilka różnych kryteriów podziału tej grupy inwestorów, które odzwierciedlają ich strategie i motywy działania, co zaprezentowano w tabeli 2. 


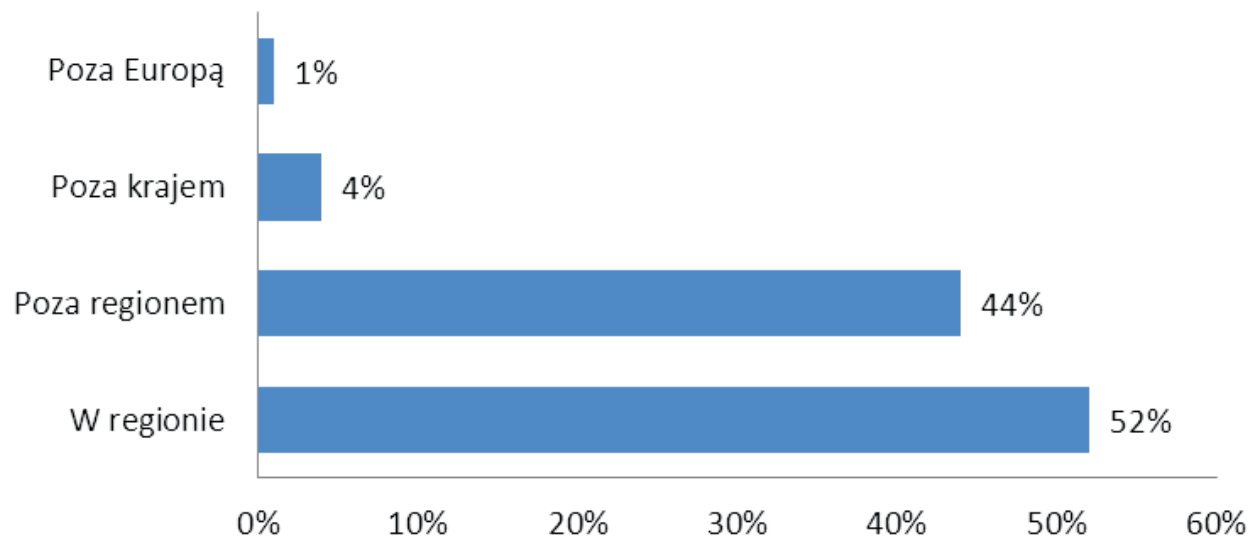

Wykres 6. Lokalizacja inwestycji w stosunku do lokalizacji aniołów biznesu

Źródło: opracowanie własne na podstawie danych EBAN 2014.

Tabela 2. Rodzaje inwestorów business angels

\begin{tabular}{|c|c|c|}
\hline $\begin{array}{l}\text { Kryterium } \\
\text { podziału }\end{array}$ & $\begin{array}{l}\text { Rodzaj anioła } \\
\text { biznesu }\end{array}$ & Charakterystyka anioła \\
\hline \multirow[t]{6}{*}{$\begin{array}{l}\text { Poziom } \\
\text { biznesowej } \\
\text { aktywności } \\
\text { i intensywności } \\
\text { inwestowania }\end{array}$} & $\begin{array}{l}\text { Aniot } \\
\text { przedsiębiorca }\end{array}$ & $\begin{array}{l}\text { Inwestor o najwyższej aktywności ze względu na licz- } \\
\text { bę dokonanych transakcji i wielkość zainwestowanego } \\
\text { kapitału. To osoba, którą cechuje ogromne doświad- } \\
\text { czenie biznesowe i wysoki status majątkowy, prefe- } \\
\text { rująca inwestycje w początkujące projekty (start-up), } \\
\text { a głównym kryterium inwestycji jest osobowość przed- } \\
\text { siębiorcy. }\end{array}$ \\
\hline & $\begin{array}{l}\text { Aniot } \\
\text { poszukujący } \\
\text { dochodu }\end{array}$ & $\begin{array}{l}\text { Jest mniej majętny i mniej aktywny, ale motywacją } \\
\text { jego działania są korzyści majątkowe i chęć stworzenia } \\
\text { sobie miejsca pracy. Wybiera branże, na których się zna } \\
\text { i angażuje się menedżersko. }\end{array}$ \\
\hline & $\begin{array}{l}\text { Aniot } \\
\text { korporacyjny }\end{array}$ & $\begin{array}{l}\text { Inwestor należący do kadry zarządzającej najwyższego } \\
\text { szczebla, a motywacją jego działań są potencjalne ko- } \\
\text { rzyści majątkowe. }\end{array}$ \\
\hline & $\begin{array}{l}\text { Aniot } \\
\text { maksymalizujący } \\
\text { bogactwo }\end{array}$ & $\begin{array}{l}\text { Inwestuje w kilka przedsięwzięć jednocześnie z zamia- } \\
\text { rem osiągnięcia wysokiej stopy zwrotu. }\end{array}$ \\
\hline & $\begin{array}{l}\text { Anioł } \\
\text { początkujący }\end{array}$ & $\begin{array}{l}\text { Inwestor, który posiada najmniejszy majątek, a zara- } \\
\text { zem najmniejsze możliwości inwestowania spośród } \\
\text { wszystkich typów aniołów. Inwestuje na rynku niepu- } \\
\text { blicznym w celu osiągnięcia wyższej stopy zwrotu niż } \\
\text { na rynku publicznym. Dodatkowo zatrudnia się w fir- } \\
\text { mie, do której wnosi kapitat. }\end{array}$ \\
\hline & Anioł uśpiony & $\begin{array}{l}\text { Inwestor pasywny, który posiada dość duże środki fi- } \\
\text { nansowe, ale nie inwestował ich ze względu na brak } \\
\text { ofert i informacji. Kładzie duży nacisk na bliskość tery- } \\
\text { torialną projektu i możliwości wycofania się z inwestycji. }\end{array}$ \\
\hline
\end{tabular}




\begin{tabular}{|l|l|l|}
\hline $\begin{array}{c}\text { Kryterium } \\
\text { podziału }\end{array}$ & \multicolumn{1}{|c|}{$\begin{array}{c}\text { Rodzaj anioła } \\
\text { biznesu }\end{array}$} & \multicolumn{1}{c|}{ Charakterystyka anioła } \\
\hline $\begin{array}{l}\text { Motywacja } \\
\text { inwestorów }\end{array}$ & $\begin{array}{l}\text { Anioł economic } \\
\text { investors }\end{array}$ & $\begin{array}{l}\text { Inwestuje z pobudek czysto finansowych dla osiągnię- } \\
\text { cia maksymalnego zysku i akceptuje maksymalne ry- } \\
\text { zyko. }\end{array}$ \\
\cline { 2 - 3 } & Anioł hedonista & $\begin{array}{l}\text { Stawia bardziej na biznesową przygodę, czyli zadowo- } \\
\text { lenie z udziału w projekcie, niż finansowy wymiar in- } \\
\text { westycji. }\end{array}$ \\
\cline { 2 - 3 } & Anioł altruista & $\begin{array}{l}\text { Dokonuje inwestycji, kieruje się motywami pozaeko- } \\
\text { nomicznymi, biorąc pod uwagę aspekty społeczne. }\end{array}$ \\
\hline
\end{tabular}

Źródło: opracowanie własne na podstawie Tamowicz 2007, s. 17-19; Michalski, Piocha 2008, s. 404-405 na podstawie badań Wspólnotowego Serwisu Informacyjnego Badań i Rozwoju CORDIS.

Znajomość typologii inwestorów występujących na rynku ma duże znaczenie i jest bardzo praktyczna zarówno dla przedsiębiorców poszukujących kapitału, jak i dla sieci skupiających anioły biznesu. Przedsiębiorcom świadomym takich podziałów łatwiej będzie znaleźć odpowiednich kapitałodawców dla swoich projektów.

Aniołowie biznesu finansują relatywnie ryzykowne projekty inwestycyjne, głównie w początkowych fazach rozwoju (seed, start-up), angażując swoje środki, $\mathrm{z}$ reguły od 100 tys. do $1 \mathrm{mln}$ zł na okres od 3 do 7 lat. Wyłączają ze swojego portfela inwestycyjnego projekty z przemysłu zbrojeniowego, tytoniowego i rynku nieruchomości, a wybierają głównie rozwojowe branże przedstawione na wykresie 7.

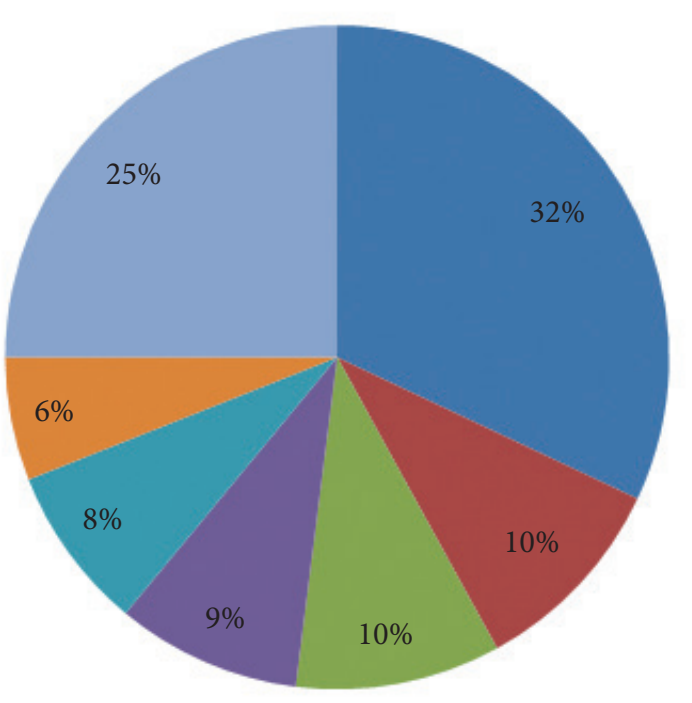

Informatyka

Biotechnologia i nauki

przyrodnicze

Telefonia komórkowa

Przemysł

Opieka zdrowotna

Energetyka

Wykres 7. Branże, w które inwestowali aniołowie biznesu w 2013 roku Źródło: opracowanie własne na podstawie danych EBAN 2014. 
Rynek aniołów biznesu w Polsce jest jeszcze bardzo młody. Aniołowie biznesu nie są zbiorowością jednorodną, pomimo że mają wspólne, biznesowe korzenie i łączy ich ten sam cel - pomnażanie majątku. Rozwój rynku nieformalnych inwestorów przyczynił się do zmiany sposobu ich funkcjonowania i wymusił tworzenie lokalnych, regionalnych i ogólnokrajowych sieci, które zajmują się bezpośrednim łączeniem projektodawców, którzy mają propozycję inwestycyjną i inwestorów (kapitałodawców). Business Angels w Polsce koncentrują się w głównej mierze wokół sieci aniołów biznesu, które w większości zostały sfinansowane przez Program Operacyjny Innowacyjna Gospodarka, realizowany w latach 2007-2013 (Wieczyński, Jura, Bijas, Dąbrowska 2012).

W ujęciu globalnym skala inwestycji aniołów biznesu jest praktycznie niemierzalna. Należy tu zwrócić uwagę na fakt, że anioły biznesu to nie tylko inwestorzy, których skupiają sieci, ale także grono niezrzeszonych inwestorów, którym własne doświadczenie i kontakty wystarczają do pozyskania ciekawych przedsięwzięć inwestycyjnych, a o których nic nie wiadomo, dopóki projekt nie stanie się widoczny na rynku. Aniołowie biznesu w Polsce to najczęściej mężczyźni w wieku od 35 do 65 lat, którzy posiadają wykształcenie wyższe, wysokie wartości aktywów, a w ich portfel inwestycyjny obejmuje 2-5 spółek, w które inwestują średnio od 100000 do 1000000 złotych, co stanowi ok. 15\% aktywów netto. Incydentalne dane na temat rozmiarów rynku aniołów biznesu wskazują na to, iż jego znaczenie w zaspokajaniu obszarów luki kapitałowej nie jest wcale marginalne (wykres 8).

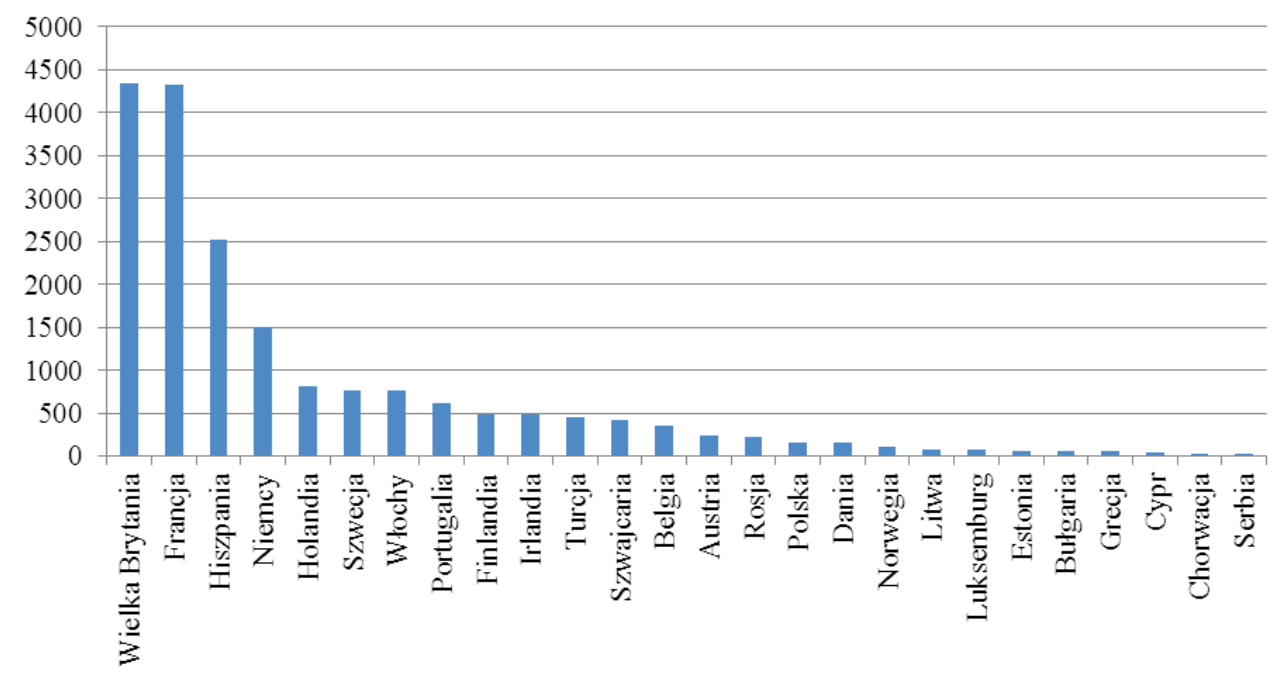

Wykres 8. Liczba aniołów biznesu w krajach europejskich

Źródto: opracowanie własne na podstawie danych EBAN 2014.

Największa liczba sieci aniołów biznesu (83) funkcjonuje we Francji (wykres 9). Polska uplasowała się w roku $2013 \mathrm{w}$ połowie tego zestawienia z liczbą 4 sieci aniołów biznesu. 


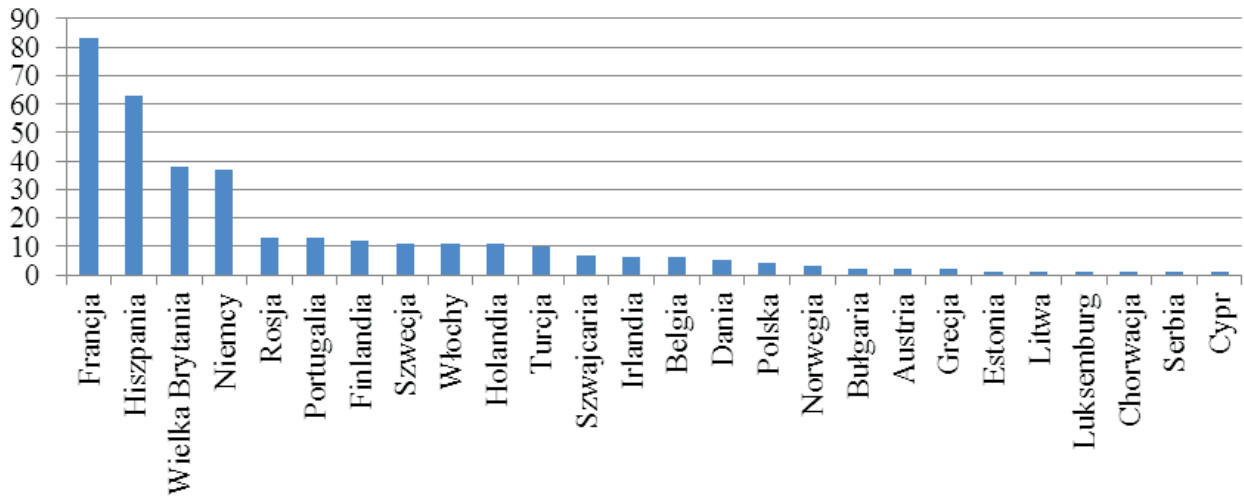

Wykres 9. Liczba sieci aniołów biznesu w krajach europejskich Źródło: opracowanie własne na podstawie danych EBAN 2014.

W roku 2016 na terenie Rzeczypospolitej Polskiej znajdowało się 15 działających, regionalnych sieci aniołów biznesu, które zostały przedstawione w tabeli 3. Większość z sieci nie posiada osobowości prawnej i działa w ramach większej organizacji lub stowarzyszenia. Według szacunków Ministerstwa Gospodarki z każdą z sieci działa ok. 30 aniołów biznesu. W Polsce sieci aniołów biznesu poszukują projektów, których potrzeby na kapitał wahają się w granicach od 50000 do $5000000 \mathrm{z}$.

Tabela 3. Sieci aniołów biznesu w Polsce

\begin{tabular}{|l|l|c|}
\hline \multicolumn{1}{|c|}{ Nazwa sieci } & \multicolumn{1}{c|}{ Miasto } & $\begin{array}{c}\text { Rok } \\
\text { powstania }\end{array}$ \\
\hline Business Angels Club & Warszawa, Bydgoszcz & 2003 \\
\hline Lewiatan Business Angels & Warszawa & 2005 \\
\hline Śląska Sieć Aniołów Biznesu Siliban & Katowice & 2006 \\
\hline Sieci Inwestorów Prywatnych SATUS & Kraków & 2006 \\
\hline $\begin{array}{l}\text { Regionalna Sieć Inwestorów } \\
\text { i Inwestycji Kapitałowych RESIK }\end{array}$ & Kraków & 2007 \\
\hline Wschodnia Sieć Aniołów Biznesu & Lublin & 2007 \\
\hline Sieć Aniołów Biznesu Amber & Szczecin & 2009 \\
\hline Secus Wsparcie Biznesu & $\begin{array}{l}\text { Poznań, Warszawa, Katowice, Kraków, } \\
\text { Proctaw }\end{array}$ & 2010 \\
\hline Biznesu - Innowacja & Katowice, Warszawa, Wrocław, Białystok, & 2010 \\
\hline Gildia Aniołów Biznesu & Gorzów Wielkopolski, Zielona Góra & 2010 \\
\hline Studencka Sieć Aniołów Biznesu & Łódź & 2011 \\
\hline Platinum Investors & Katowice, Warszawa, Wrocław, Białystok & 2012 \\
\hline Kobieca Sieć Aniołów Biznesu & Gdynia, Warszawa & 2012 \\
\hline Smart Business Angels & Katowice, Warszawa, Wrocław & 2013 \\
\hline Technology Investors Business Angels & Warszawa & 2013 \\
\hline
\end{tabular}

Źródło: opracowanie własne. 
Z roku na rok rośnie liczba firm, które zostały zasilone finansowo przez business angels w krajach europejskich. Wyraźnym liderem jest tutaj Wielka Brytania, która ma na swoim koncie 535 zrealizowanych projektów (wykres 10).

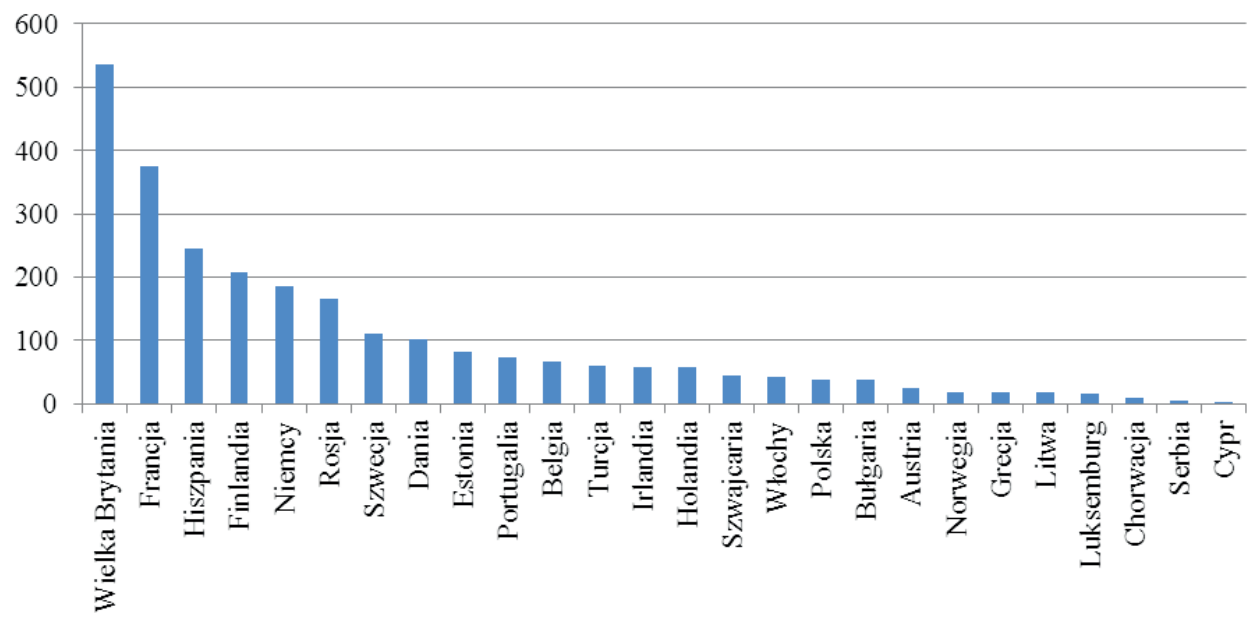

Wykres 10. Liczba finansowanych przedsiębiorstw w krajach europejskich Źródło: opracowanie własne na podstawie danych EBAN 2014.

Dzięki inwestycjom aniołów biznesu powstały nowe miejsca pracy (wykres 11). Liderem jest również Wielka Brytania, która odnotowała powstanie 2354 nowych miejsc pracy. Na tym tle Polska wypada blado z 233 nowymi etatami.

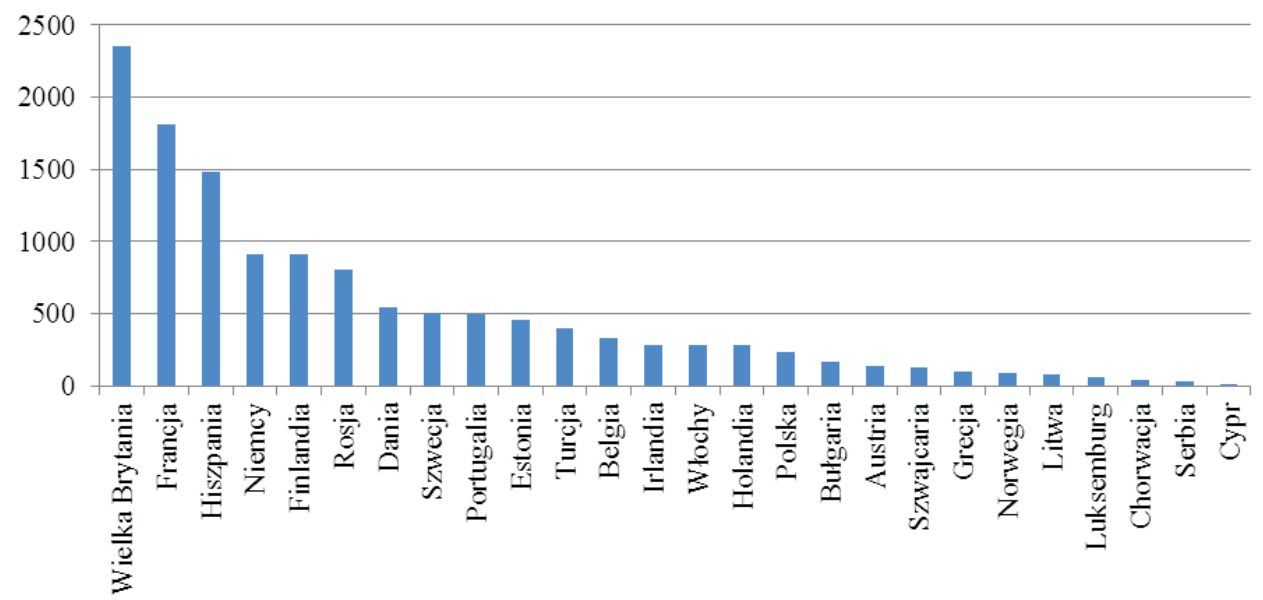

Wykres 11. Liczba utworzonych miejsc pracy w krajach europejskich

Źródto: opracowanie własne na podstawie danych EBAN 2014.

Inwestycje aniołów biznesu zostały zrealizowane w Wielkiej Brytanii na kwotę 84,4 mln euro, natomiast polski rynek aniołów biznesu odnotował inwestycje o wartości 6,6 mln euro (wykres 12). 


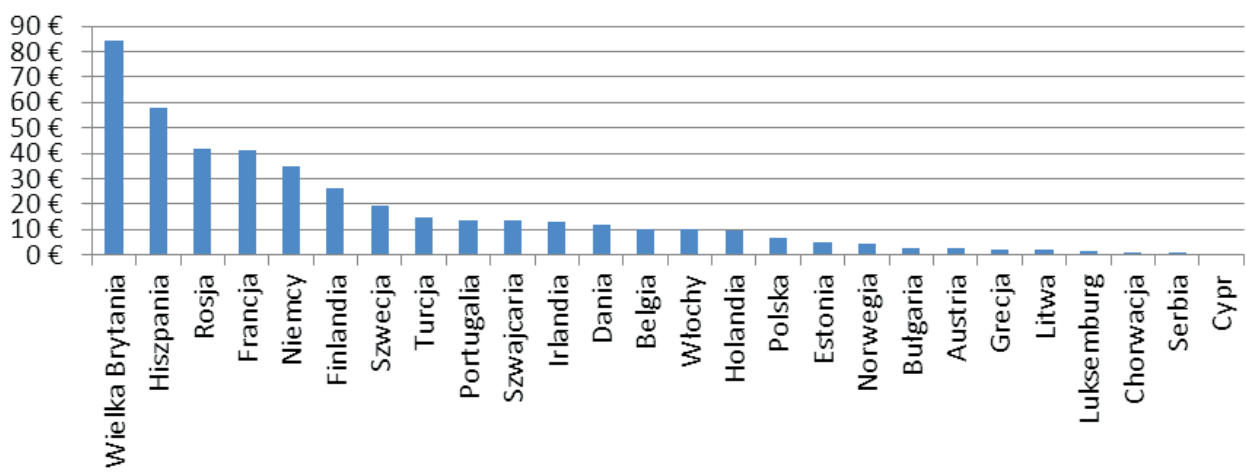

Wykres 12. Łączna suma inwestycji aniołów biznesu w krajach europejskich w mln euro Źródło: opracowanie własne na podstawie danych EBAN 2014.

Średnia suma inwestycji przypadająca na polskiego anioła biznesu wynosi 41125 euro (wykres 13) i jest porównywalna do Grecji i Norwegii. Najlepszy wynik odnotowała Rosja z kwotą 189773 euro. Mimo że Francję charakteryzuje duży potencjał rynku busines angels, to kwota ta wynosi tylko 9502 euro.

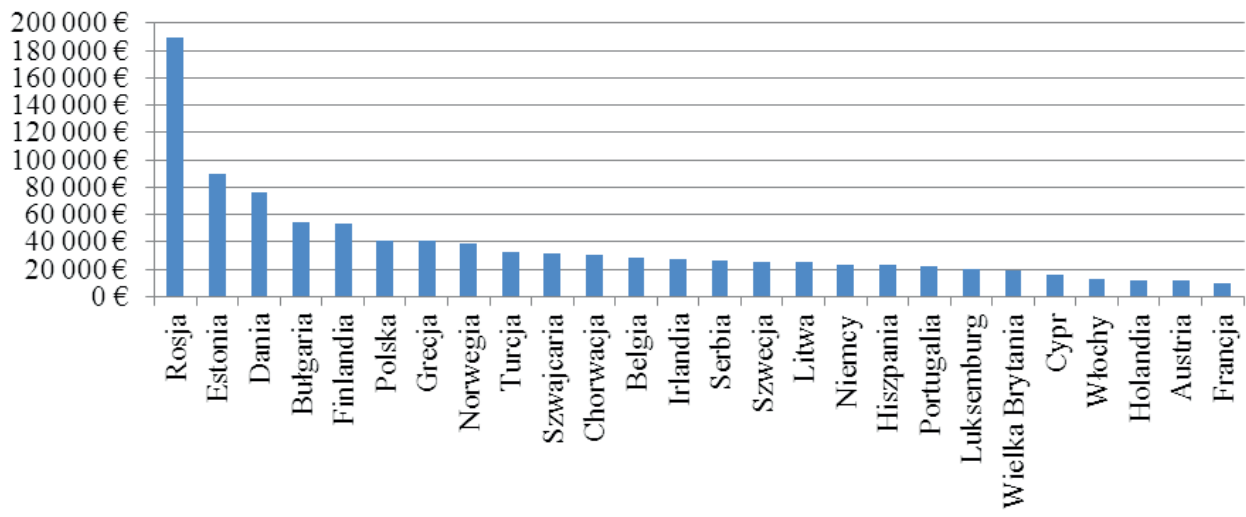

Wykres 13. Średnia suma inwestycji przypadająca na anioła biznesu w krajach europejskich w euro Źródło: opracowanie własne na podstawie danych EBAN 2014.

Na wykresie 14 przedstawiono średnią sumę inwestycji przypadającą na sieć aniołów biznesu. I tutaj pierwsze miejsce zajmuje Estonia (4,7 mln euro), a ostatnie Francja $(0,5 \mathrm{mln}$ euro). Na polską sieć przypada średnia kwota $1,6 \mathrm{mln}$ euro.

Inwestorzy indywidualni business angels odgrywają znaczącą rolę w finansowaniu rozwoju europejskiej gospodarki. Istnieje potrzeba zwiększenia ich udziału w stymulowaniu rozwoju start-upów w Polsce, które wpływają na wzrost innowacyjności całej gospodarki. 


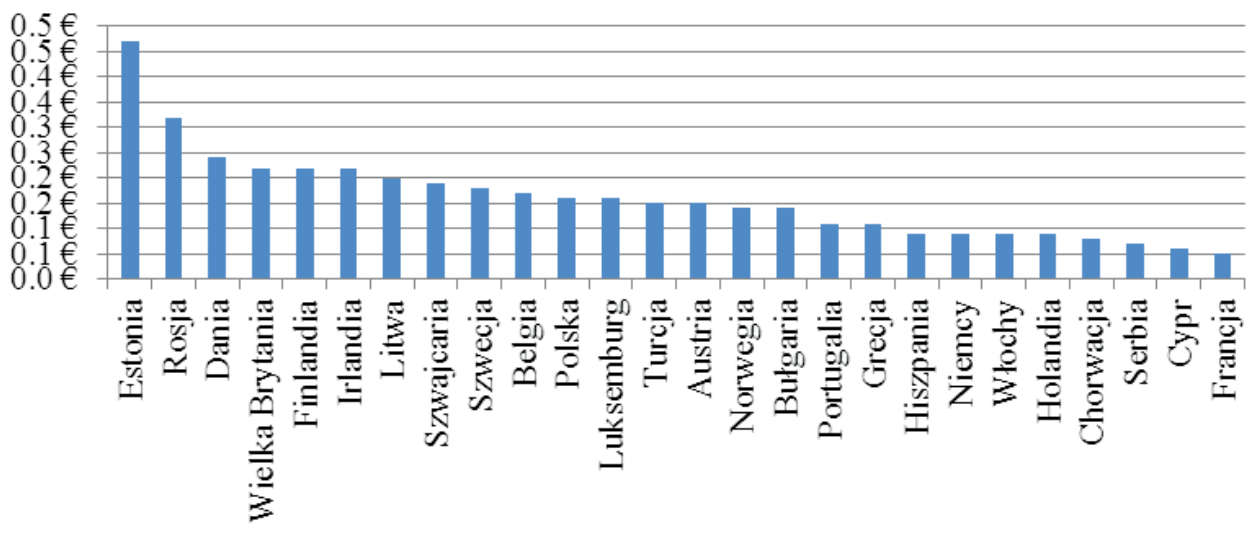

Wykres 14. Średnia suma inwestycji przypadająca na sieć aniołów biznesu w krajach europejskich w mln euro

Źródło: opracowanie własne na podstawie danych EBAN 2014.

\section{Podsumowanie}

Aniołowie biznesu pełnią bardzo ważną rolę na rynku kapitału ryzyka. Aktywnie oddziałują na zmniejszenie luki kapitałowej występującej w potrzebach start-upów. Zapewniają dostęp do kapitału nowym, innowacyjnym firmom, bez którego nie mogłyby funkcjonować i rozwijać się. Business angels stanowią więc kluczowy element rozwoju przedsiębiorstw, stymulując rozwój sektora małych i średnichfirm. Dlatego należy tworzyć zachęty fiskalne dla potencjalnych inwestorów i zwiększyć poziom wiedzy z zakresu finansów i przedsiębiorczości. Przełoży się to na wzrost realizowanych przez anioły biznesu inwestycji i znaczny wzrost innowacyjności polskiej gospodarki.

\section{Bibliografia}

Bosma N., Wennekers S., Amoros J.E. (2012), Global Entrepreneurship Monitor 2011 Extended Report: Entrepreneurship and Entrepreneurial Employees Across the Globe, London, GERA.

European Business Angels Network, Statistic Compendium EBAN (2014), http://www.eban.org/wp-content/uploads/2014/09/13.-Statistics-Compendium-2014.pdf

Global Entrepreneurship Monitor (2011-2014).

Global Entrepreneurship Monitor - Polska (2014), Raport z badania.

Michalski E., Piocha S. (red.) (2008), Instytucjonalne i rynkowe uwarunkowania rozwoju małych $i$ średnich przedsiębiorstw w Polsce, Polskie Towarzystwo Ekonomiczne, Koszalin. 
Piekunko-Mantiuk I. (2014), Aniołowie biznesu i ich rola w finansowaniu startupów, Ekonomia i Zarządzanie, $\mathrm{Nr} 4(6)$.

Porter M.E., Sachs J.D., Mc Arthur J.W. (2002), Executive Summary: Competitiveness and Stages of Economic Development, [in:] M.E. Porter, J.D. Sachs, J.W. Mc Arthur, K. Schwab (red.), The Global Competitiveness Report 2001-2002, Oxford University Press, New York.

Smus T.R. (2014), Finansowanie start-upów w Polsce, Zeszyty Naukowe Uczelni Vistula, 35.

Strzelczyk D. (2015), Mam pomysł na biznes i potrzebuję kapitału na start, http://startupacademy.pl/ pomysl-na-biznes-kapital-na-start

Symanowitz C. (2014), Start-up versus corporate: which one's for you?, http://colettesymanowitz. com/2014/07/09/start-up-versus-corporate-which-ones-for-you

Tamowicz P. (2007), Business angels. Pomocna dłoń kapitału, Polska Agencja Rozwoju Przedsiębiorczości, Gdańsk.

Wieczyński P., Jura P., Bijas A., Dąbrowska E. (2012), Bariery w rozwoju rynku aniołów biznesu w Polsce, http://www.finansedlainnowacji.pl/wpcontent/uploads/2012/08/Bariery_w_rozwoju_rynku _aniolow_biznesu_w_Polsce_WEB.pdf

\section{BUSINESS ANGELS JAKO ALTERNATYWNE ŹRÓDŁO FINANSOWANIA START-UPÓW}

\section{Streszczenie}

Podmioty gospodarcze jako element każdego modelu gospodarki są bardzo istotne z punktu widzenia funkcjonowania każdego systemu ekonomicznego na świecie. Stan gospodarki jest bowiem silnie zależny od dynamicznego rozwoju sektora przedsiębiorczości. Zależność ta zachodzi na wszystkich etapach rozwoju gospodarczego, może ona jednak przybierać różne nasilenie i charakter.

W Polsce, podobnie jak na całym świecie, powstaje wiele nowych przedsiębiorstw. Główną barierą ich rozwoju w początkowej fazie jest niewątpliwie brak kapitału. Wdrożenie i realizacja obiecujących pomysłów jest bardzo często niemożliwa z powodu braku funduszy. Dlatego też celem niniejszego artykułu jest ocena roli aniołów biznesu w finansowaniu przedsiębiorstw w zalążkowej lub początkowej fazie rozwoju.

Aniołowie biznesu pełnią bardzo ważną rolę na rynku kapitału ryzyka. Aktywnie oddziałują na zmniejszenie luki kapitałowej występującej w potrzebach start-upów. Zapewniają dostęp do kapitału nowym, innowacyjnym firmom, bez którego nie mogłyby funkcjonować i rozwijać się. Business angels stanowią więc kluczowy element rozwoju przedsiębiorstw, stymulując rozwój sektora małych i średnich firm Dlatego należy tworzyć zachęty fiskalne dla potencjalnych inwestorów i zwiększyć poziom wiedzy z zakresu finansów i przedsiębiorczości. Przełoży się to na wzrost realizowanych przez anioły biznesu inwestycji i znaczny wzrost innowacyjności polskiej gospodarki.

Słowa kluczowe: anioł biznesu, sieć aniołów biznesu, finansowanie start-upów

\section{BUSINESS ANGELS AS AN ALTERNATIVE SOURCE OF FINANCING START-UPS}

\section{Summary}

Business entities which are element of every economy model are crucial for functioning of all economical systems in the world. Economy condition is strongly dependent on development of entrepreneurial sector. That dependence takes place on all stages of economic development, however it can differ in intensity and its nature. In Poland just as in the whole world, a lot of new 
companies are being created. Their main development barrier in the early stage surely is lack of capital. Implementation and realization promising ideas is very often impossible due to funds shortage. That is why the purpose of this article is to evaluate the function of business angels in financing start-ups.

Business angels are vital part of venture capital market. They actively affect it by decreasing money scarcity in start-ups needs. They provide access to capital for new, innovative firms without which they could not operate and develop. Business angels are the key element in enterprise development at an early age of its life, stimulating growth of small and medium firms sector. Therefore, fiscal incentives should be created for potential investors and to increase knowledge level in finance and entrepreneurship fields. It will have influence on increase of executed investments and significant rise of innovativeness of polish economy.

Keywords: business angel, business angels network, start-up financing 